\title{
Influence of anthropogenic factors on microhabitats inhabited by riverine hydrobionts - assessment with MRT method
}

\author{
Zbigniew Osadowski*, Krystian Obolewski**, Agnieszka Strzelczak*** \\ *Department of Botany and Genetics, Institute of Biology and Environmental Protection, \\ Pomeranian University in Słupsk, Arciszewskiego 22B, 76-200 Słupsk \\ **Department of Aquatic Ecology, Institute of Biology and Environmental Protection, \\ Pomeranian University in Słupsk, Arciszewskiego 22B, 76-200 Słupsk \\ ***Institute of Chemistry and Environmental Protection, Szczecin University of Technology, \\ Aleja Piastów 42, 71-065 Szczecin \\ corresponding author, e-mail: osadowsk@sl.onet.pl
}

\begin{abstract}
This study concerns the influence of urban area on vegetation and invertebrates inhabiting the Słupia River (northern Poland). Altogether, 10 plant communities and 37 macrozoobenthos taxa were determined during four seasonal samplings (October 2005, January, April and August 2006). In order to reveal how the city of Słupsk affects the vegetation and fauna, MRT (multivariate regression tree) models were created. On their basis the most important factors were determined from the following set of variables: season, water temperature, salinity, distance, water depth, bottom type, location in the river bed and degree of river bed transformations. Performed analyses showed that vegetation in the urban area was primarily influenced by distance (correlated with anthropogenic pressure), while for invertebrates season and temperature were the most important factors.
\end{abstract}

Key words: vegetation, invertebrates, anthropopression, multivariate regression trees, the Słupia River, northern Poland.

\section{Introduction}

Large urban areas are one of the most important objects in river basins affecting aquatic ecosystems (Obolewski et al. 2004). That influence is particularly visible in the case of small watercourses with only one conurbation located in their area. They give a possibility to thoroughly analyse qualitative and quantitative changes of vegetation and fauna communities induced by anthropopressure (Allan 1997).

So far hydrobiological research in the Stupia River basin have been rather fragmentary and could hardly be used as a basis in a reliable assessment of the river ecological state (Obolewski et al. 2004). They also lack detailed analyses of vegetation and macrozoobenthos in the Słupsk urban area, including anthropogenic pressure on these ecological formations. This study fills in that gap in the knowl- edge and concerns the influence of the city of Stupsk on vegetation and invertebrates inhabiting microhabitats in the Słupia River. As a mathematical modelling tool the MRT (multivariate regression tree) technique was chosen in order to indicate factors influencing the multivariate vegetation and macrozoobenthos communities.

\section{Study area}

The Stupia River is one of the longest rivers in Middle Pomerania (Poland) with the total length of $138.6 \mathrm{~km}$ and the river basin area of $1623 \mathrm{~km}^{2}$. In its drainage area there is only one urban agglomeration- the city of Słupsk. Słupia flows into Slupsk at the 39th $\mathrm{km}$ of its course forming a wide, unregulated riverbed. In the suburbs, the river is fenced with a mill weir (concrete banks). Within the city 


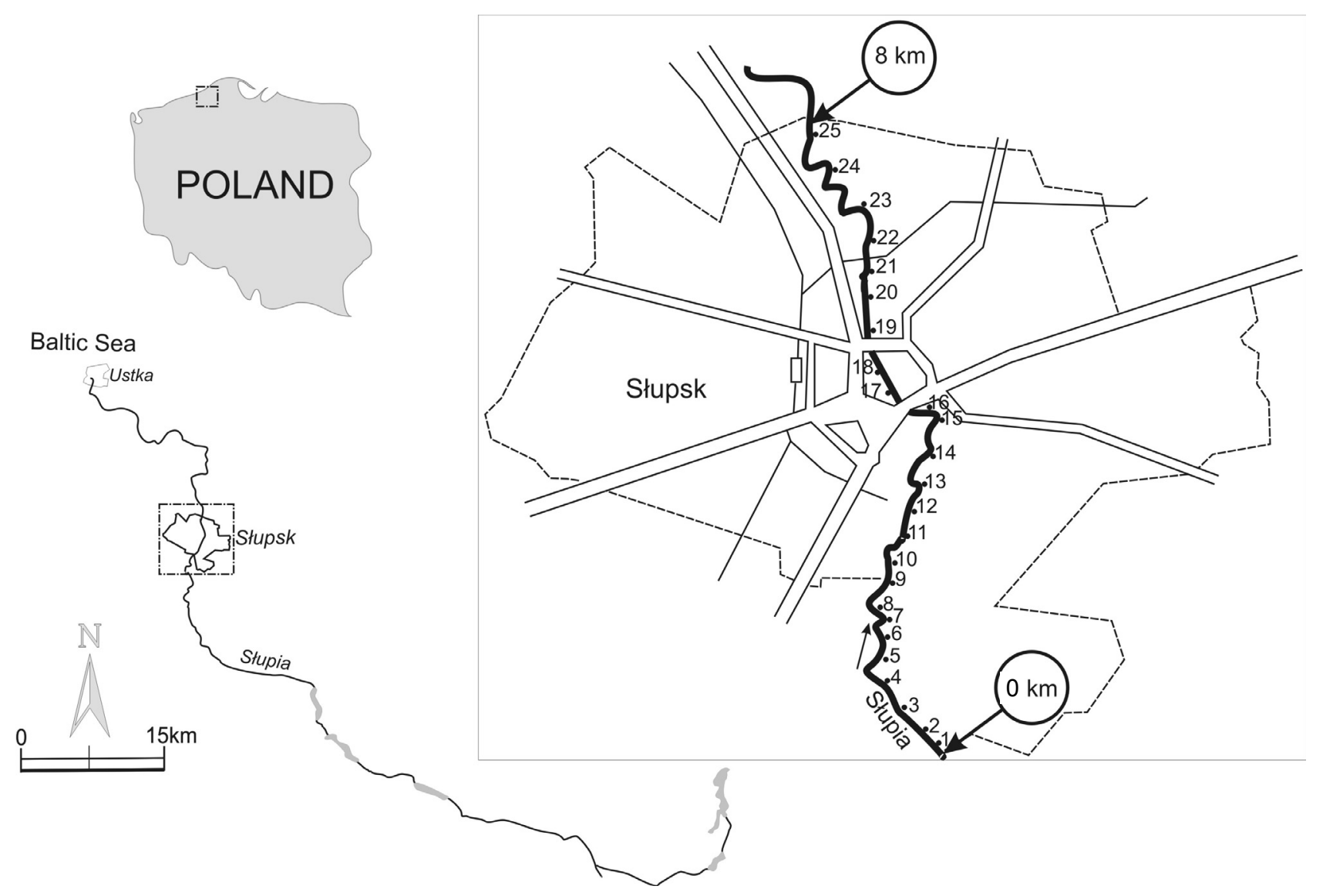

Figure 1. Location of the Stupia River and distribution of sampling sites

(between the 37 th and 34th $\mathrm{km}$ ) it is tamed and at then, at the $36 \mathrm{th} \mathrm{km}$, divided into the main riverbed and the mill channel. Passing by the buildings, Stupia gets wider and forms natural meanders (Piechura et al. 1997). The river length within Słupsk is $8 \mathrm{~km}$ and the riverbed is fairly diversified with various microhabitats, which can be inhabited by vegetation and invertebrates of different, even extreme environmental requirements.

\section{Material and methods}

\section{Sampling}

Qualitative and quantitative studies of macrozoobenthos communities were conducted seasonally in the coastal zone at 25 sampling sites (Fig. 1) from November 2005 till August 2006, four times at each site. The distance, measured from $1 \mathrm{~km}$ before the first sampling station down the river, was treated as a surrogate variable for the direct impact of the city on hydrobionts, due to the lack of, for instance, trophic parameters.
Qualitative structure of plant communities was identified in autumn 2005 with the Braun-Blanquet method (Medwecka-Karnaś et al. 1972). 33 phytosociological relevés indicated plant communities present all year round. Plant assemblages (phytocoenoses; Matuszkiewicz 2001) were assumed to be the basic phytosociological units and distinguished without a syntaxonomic rank. Selected habitat parameters of the distinguished plant communities were analysed with the help of Ellenberg index numbers (Ellenberg et. al. 1992). On their basis habitat fertility was determined for phytocoenoses, within the range $1-10$ (the higher fertility, the lower number). The type, the number of phytocoenoses and their preferences for habitat fertility were used in order to determine the quantitative biodiversity factor at the consecutive sampling sites. The final biodiversity index was obtained by summing up the assigned values of habitat preferences (Tab. 1).

Densities of benthic invertebrates were determined according to the following ISO norms- 78278:1985 and $8265: 1988$, complemented by a higher degree of standardization and specified by Böhmer et al. (1999). The main 


\begin{tabular}{|c|c|c|c|c|c|c|c|c|c|c|c|c|c|c|c|c|c|c|c|c|c|c|}
\hline & әวนว...กววO & & & & 6 & $a$ & $=$ & & + & & $m$ & & & & - & - & - & $\infty$ & & - & & \\
\hline & $\ddot{\sim}$ & & & & ' & 1 & + & & ' & & + & & & & ' & ' & ' & & & ' & $\sim$ & $\stackrel{\circ}{ }$ \\
\hline & $\stackrel{d}{d}$ & & & & , & ' & & & , & & + & & & & . & 1 & 1 & & & ' & - & $a$ \\
\hline & $\tilde{\sim}$ & & & & ' & ' & & & ' & & ' & & & & ' & ' & I & + & & ' & - & $m$ \\
\hline & ส & & & & + & 1 & & & 1 & & + & & & & ' & ' & ' & 1 & & ' & N & $m$ \\
\hline & $\vec{\sim}$ & & & & ' & 1 & + & & ' & & ' & & & & ' & ' & ' & ' & & ' & - & - \\
\hline & ิㅗ & & & & + & ' & + & & ' & & , & & & & ' & ' & , & , & & ' & $N$ & in \\
\hline & $\curvearrowright$ & & & & , & I & + & & ' & & , & & & & 1 & ' & 1 & 1 & & , & - & - \\
\hline & $\stackrel{\infty}{\sim}$ & & & & , & I & & & 1 & & , & & & & ' & ' & + & + & & ' & $N$ & in \\
\hline & $=$ & & & & . & ' & + & & 1 & & , & & & & 1 & , & 1 & 1 & & , & - & - \\
\hline & 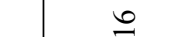 & & & & + & + & & & 1 & & 1 & & & & 1 & , & 1 & + & & , & $m$ & 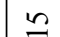 \\
\hline & $\because$ & & & & , & + & + & & 1 & & 1 & & & & 1 & , & + & + & & , & t & $\Xi$ \\
\hline & $\stackrel{\mathscr{n}}{.}$ & & & & + & 1 & 1 & & 1 & & 1 & & & & + & 1 & 1 & + & & , & $m$ & 0 \\
\hline & $\stackrel{80}{.0}$ & & & & + & + & + & & 1 & & 1 & & & & 1 & 1 & 1 & 1 & &, & $m$ & $m$ \\
\hline & $\bar{\Xi}$ & & & & 1 & + & + & & 1 & & , & & & & 1 & 1 & , & + & & , & $m$ & $\checkmark$ \\
\hline \multirow{12}{*}{ 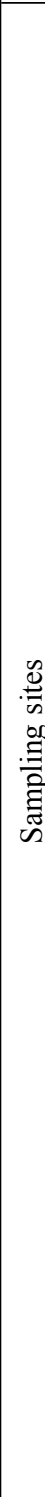 } & $=$ & & & & 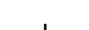 & t & + & & 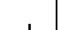 & & , & & & & 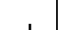 & & 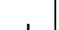 & 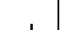 & & , & - & - \\
\hline & 0 & & & & & 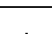 & +1 & & & & 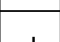 & & & & & & & 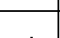 & & & 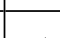 & 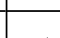 \\
\hline & & & & & & & & & & & & & & & & & & & & & & \\
\hline & $a$ & & & & ' & ' & + & & 1 & & ' & & & & 1 & ' & ' & 1 & & ' & - & - \\
\hline & $\infty$ & & & & ' & + & 1 & & 1 & & 1 & & & & 1 & ' & 1 & 1 & & ' & - & $\infty$ \\
\hline & $r$ & & & & ' & ' & 1 & & ' & & ' & & & & ' & ' & ' & + & & ' & - & $m$ \\
\hline & 0 & & & & ' & ' & 1 & & 1 & & ' & & & & ' & + & ' & ' & & ' & - & in \\
\hline & in & & & & ' & + & 1 & & + & & ' & & & & 1 & ' & 1 & + & & ' & $m$ & $\bar{\sim}$ \\
\hline & ナ & & & & ' & ' & ' & & I & & ' & & & & ' & ' & , & ' & & + & - & 0 \\
\hline & $m$ & & & & ' & + & 1 & & + & & ' & & & & ' & ' & I & ' & & ' & $\alpha$ & $\stackrel{\infty}{\sim}$ \\
\hline & $\sim$ & & & & ' & + & 1 & & + & & ' & & & & ' & ' & I & ' & & ' & $\alpha$ & $\infty$ \\
\hline & - & & & & + & + & ' & & + & & ' & & & & ' & ' & , & ' & & ' & $m$ & ส \\
\hline & 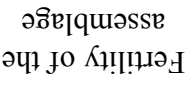 & & & & $\nabla$ & $\infty$ & - & & 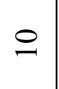 & & $a$ & & & & $r$ & in & $\sim$ & $m$ & & 0 & & \\
\hline & 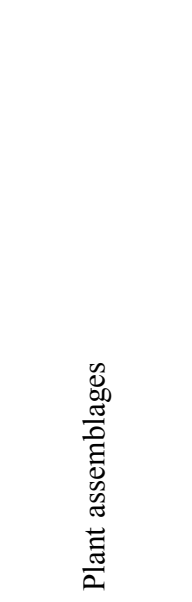 & 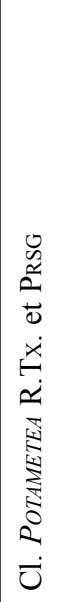 & 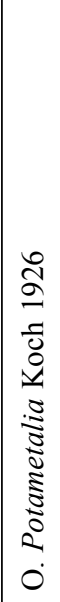 & 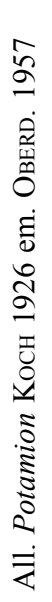 & 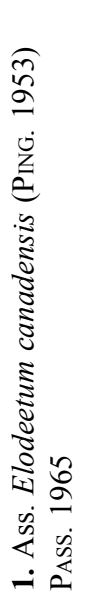 & 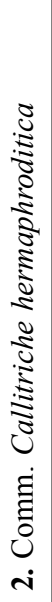 & 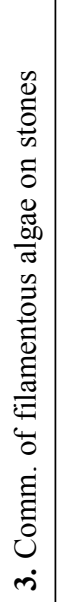 & 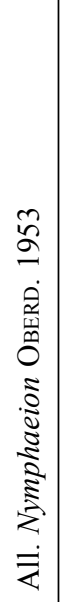 & 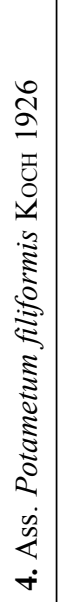 & 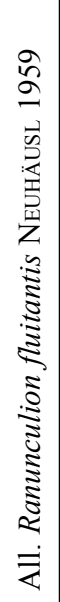 & 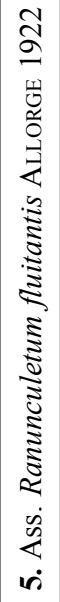 & 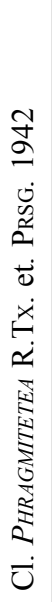 & 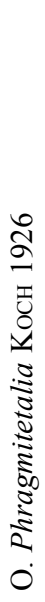 & 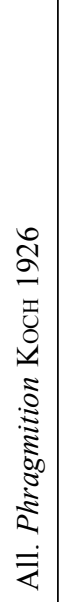 & 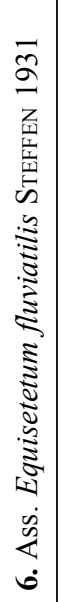 & 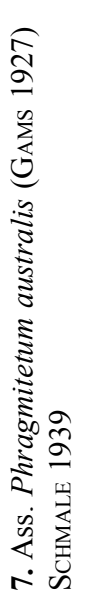 & 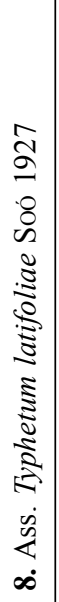 & 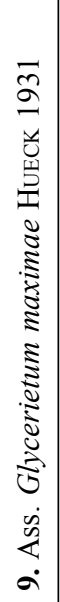 & 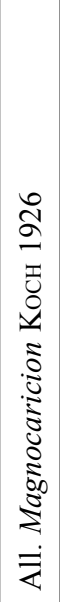 & 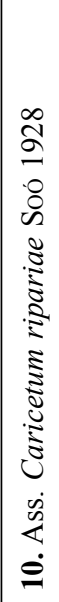 & 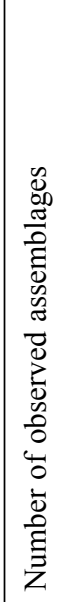 & 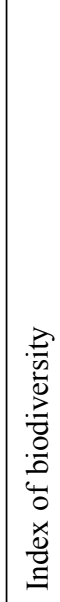 \\
\hline
\end{tabular}


advantage of this method is standardization of all sampled sections, using a D-frame aquatic net of $0.5 \mathrm{~mm}$ mesh size, which can also sample larger stones and macrophytes. All the samples were fixed in situ and transported to the laboratory, where taxonomical identification and further analyses where performed. Except for Oligochaeta, macrozoobenthos individuals were identified at the genus level (more than $90 \%$ ).

Simultaneously with biological analyses, environmental parameters were measured at each sampling site: depth, water temperature and salinity. Substrate characteristics were determined on the basis of grain size analysis according to norms ISO 4365 and ISO 9195 and the following substrate type were specified: concrete, stones, coarse gravel, gravel, gravel with silt, sand, sand with loam, sand with silt, silt. Additionally, microhabitat types were defined as alluvion, groyne, midstream, rapids, sandy bar or steep bank. On the basis of available abiotic parameters (e.g. water chemistry, vegetation characteristics, bottom morphology), the degree of anthropogenic transformations of the riverbed was classified into three categories - low (reference level), medium and high. Methodology of this division was in accordance with bio-assessment criteria (e.g. Barbour et al. 1997, 1996).

Additionally, biodiversity of benthic fauna was assessed with the Shannon index ( $\left.\mathrm{H}^{\prime}\right)$, calculated for the whole year at the consecutive sampling sites using BioDiversity Pro Beta 1 software (McAleece et al. 1997).

\subsection{Multivariate regression and classification trees}

The general idea of MRT is to form clusters of sites by repeating data splitting along axes of explanatory, environmental variables. Each split is selected to minimise the dissimilarity (sum of squared Euclidean distances, SSD) of taxa and sites within clusters (Breiman et al. 1984; De'ath \& Fabricus 2000; De'ath 2002).

MRT analyses the community data, but makes no assumptions about the form of relationships between species and their environment. Moreover, this method is applicable for complex ecological data with imbalance, non-linear relationships and high-order interactions. Clusters and their relationship with environmental variables are presented graphically by a tree. Each cluster represents a species assemblage and additionally the environmental values define an associated habitat.

The overall fit of the tree is specified as a relative error (Error; SSD in clusters divided by SSD of undivided data) and the predictive accuracy is assessed by CVRE (crossvalidated relative error) (Breiman et al. 1984; De'ath \& Fabricus 2000). In this study, the finally selected tree was the most complex model within one standard error (1 SE) from the best predictive tree (Breiman et al. 1984), using 2000 multiple cross validations, to stabilize CVRE. Taxa or plant assemblages distinctive for a given cluster were identified using an indicator species index (indval) calculated by the product of relative density and relative frequency of occurrence within a cluster (Dufrene \& Legendre 1997). Significance of a taxon or plant assemblage association to a particular cluster was assessed by a permutation test with 500 iterations. An indval value of 1 indicates that a taxon/ plant assemblage is solely confined to a particular cluster, while an indval of 0 indicates that a taxon is widely distributed among different clusters. Taxa/plant assemblages with indval $>0.25$ were considered as indicators, according to Dufrene \& Legendre (1997).

In this study, MRT analyses were carried out in R 2.1.1 (R Development core team 2004) using mvpart (Multivariate Partitioning) package (De'ath 2002), while indval analyses were performed with the labdsv package (Dynamic Synthetic Vegephenomenology).

\section{Results}

\subsection{Plant communities}

10 plant communities, belonging to 2 vegetation classesPotametea and Phragmitetea- were identified in the Stupia River within the limits of Słupsk (Tab. 1). Filamentous algae were dominant, present at 11 sampling sites. They inhabited submerged stones or grew directly on sandy bottom. The studied area was also rich with communities Callitriche hamulata (9 sampling sites) and Elodeetum canadensis (6 sampling sites).Whereas, the assemblage of Glycerietum maximae was frequent on muddy banks (8 sampling sites). The assemblage of Sparganium emersum was observed at 4 sites, while rare assemblage of Ranunculetum fluitantis was present at 3 sampling sites. The other phytocoenoses - Equisetetum fluviatilis, Phragmitetum australis, Typhetum latifoliaeand and Caricetum ripariae - occurred only once. The highest variety of phytocoenoses was observed at sampling site no. 15 , while at the others it varied from 1 to 3 . The biodiversity index of plant communities decreased down the river in the area of Słupsk and reached the minimum values at sampling sites subject to anthropogenic pressure to the greatest extent: no. 9-11, 17, 19 and 21.

MRT analysis (Fig. 2) revealed differences between sampling sites before and after $2.56 \mathrm{~km}$ of the investigated river section. Sparganium emersum_and Callitriche hamulta communities were indicative for 5 initial sites (indicator values 0.80 and 0.61 respectively). The multivariate division of the data set for the surrogate split- substrate type - was very closely related to the primary split with the agreement of $92 \%$. Using this split, mud and sand with mud were characteristic for the first 5 sampling sites with indicative Sparganium emersum_and Callitriche hamulta communities. The remaining substrate types were assigned 


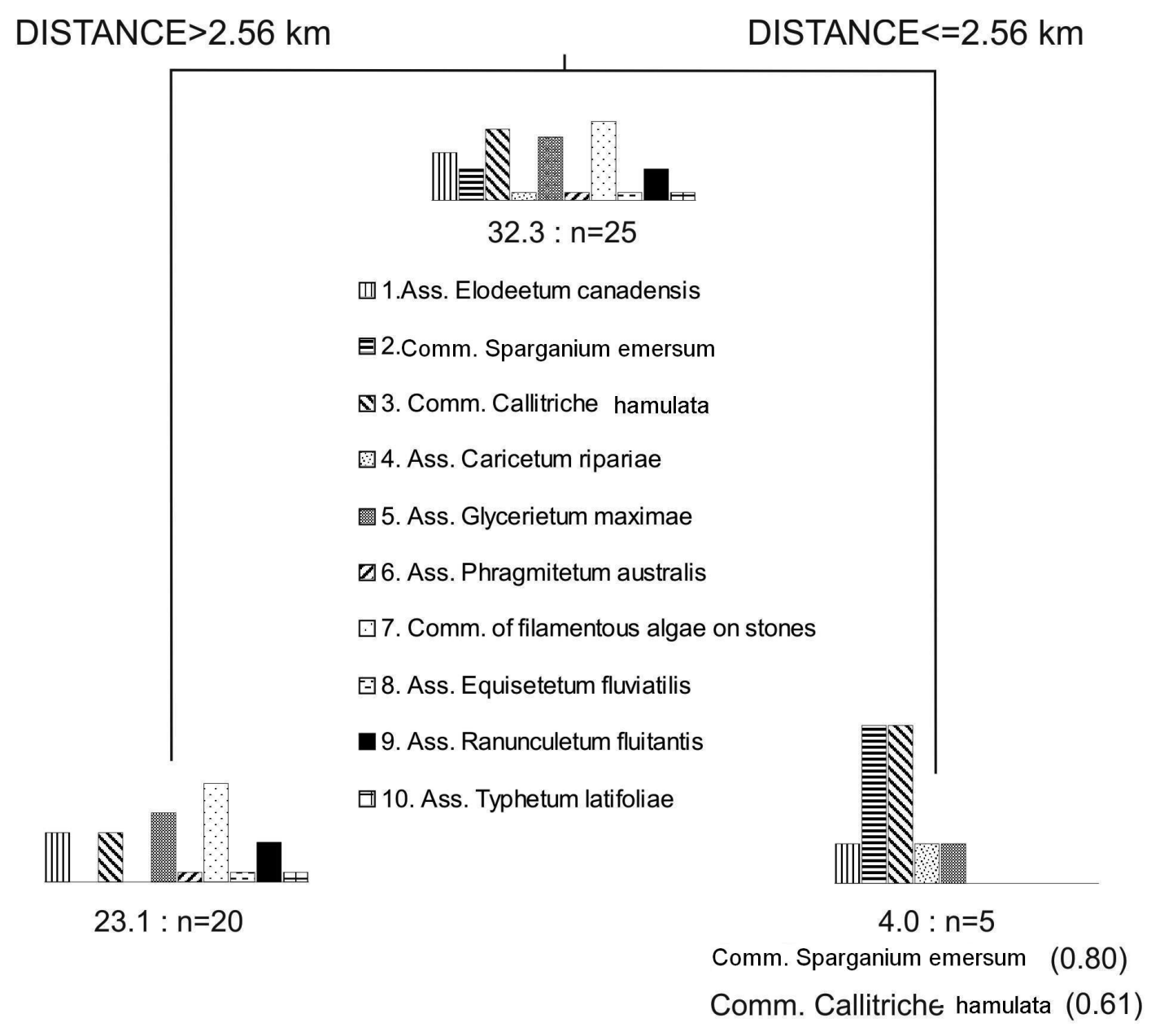

Error: 0.838 CV Error: 1.15 SE: 0.108

Figure 2. Multivariate regression tree for plant communities

to the left branch of the tree, i.e. to the next sites with the balanced occurrence frequency for the remaining identified plant communities.

\subsection{Macrozoobenthos communities}

At the studied sampling sites, 7 classes with 8 most numerous orders of insects (Tab. 2). The percentage share of consecutive taxa varied between sites. Within the whole investigated area Diptera larvae (mainly Chironomus gr. rhummi) were dominant with $52-72 \%$ of the total benthofauna density. Aside from that taxon, Oligochaeta constituted a considerable part - from $13 \%$ outside the town to $25 \%$ on the concrete riverbed. As for the rest of macrozoobenthos taxa, Gastropoda significantly contributed to the total density, especially on the highly transformed bottom (concrete).
Representatives of benthic fauna were particularly abundant at the sampling site no. 13, where the mill channel connects with the main riverbed (15 taxa). On the other hand, at the transformed sites no. 6 and 8 only 4 taxa were identified. The Shannon biodiversity index ( $\left.\mathrm{H}^{\prime}\right)$ decreased from 0.612 ahead of the city to 0.497 outside Słupsk.

The most important variable in MRT analysis of benthic fauna was the season (Fig. 3). Densities of consecutive macrozoobenthos taxa were moderately balanced in spring, summer and autumn (the left tree leaf), while in winter Oligochaeta (indval $=0.74$ ) and Diptera larvae, mainly $C h i$ ronomus gr. thummi (indval=0.60), were dominant.

The surrogate split, dividing the experimental data identically, was the temperature (agreement 100\%). Applying this variable, the right tree leaf corresponded to temperature lower than $8.0^{\circ} \mathrm{C}$ and the left one to temperature equal or higher than this threshold value. 


\begin{tabular}{|c|c|c|c|c|c|c|c|c|c|c|c|c|c|c|c|c|c|c|c|c|c|c|c|c|c|c|}
\hline & $\ddot{\sim}$ & $\stackrel{\circ}{\dot{\lambda}}$ & & ' & ' & ' & & ' & ' & ' & & ' & & ' & ' & & ' & ' & 1 & 1 & ' & & 1 & 1 & & ' \\
\hline & $\stackrel{\sim}{d}$ & $\stackrel{2}{N}$ & & $\stackrel{g}{g}$ & ' & ' & & ' & ' & 1 & & $\stackrel{\nexists}{\sim}$ & & & & & , & $\stackrel{\nexists}{-}$ & 1 & 1 & & & ' & 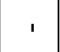 & & , \\
\hline & $\ddot{\sim}$ & zे & & $\stackrel{\sim}{\sim}$ & ' & ' & & ' & ' & ' & & ' & & ' & 1 & & 1 & 1 & 1 & ' & ' & & ' & 1 & & ' \\
\hline & $\widetilde{\sim}$ & in & & ' & ' & ' & & $\stackrel{\infty}{-}$ & ' & ' & & $\stackrel{\infty}{\rightarrow}$ & & 1 & ' & & ' & 1 & 1 & 1 & ' & & ' & ' & & ' \\
\hline & $\vec{\sim}$ & $\ddot{6}$ & & ' & ' & ' & & ' & $\hat{\sigma}$ & ' & & ' & & ' & ' & & 1 & $\stackrel{\sim}{m}$ & 1 & 1 & 1 & & , & , & & ' \\
\hline & ㄱ. & $\stackrel{n}{=}$ & & ' & ' & ' & & ' & ' & ' & & ' & & ' & 1 & & 1 & 1 & 1 & 1 & ' & & 1 & 1 & & , \\
\hline & 9 & ָָ & & ' & ' & ' & & ' & ' & ' & & ' & & ' & ' & & ' & 1 & $\stackrel{+}{\circ}$ & 1 & ' & & ' & ' & & ' \\
\hline & $\stackrel{\infty}{\infty}$ & ' & & ' & ' & $\stackrel{\circ}{i}$ & & ' & ' & ' & & $\stackrel{\circ}{+}$ & & ' & ' & $\ddot{0}$ & 1 & ' & 1 & 1 & ' & & ' & 1 & & ' \\
\hline & $=$ & $\begin{array}{l}m \\
\dot{\sigma}\end{array}$ & & i. & ' & ' & & ' & $\hat{o}$ & $\hat{o}$ & & $\hat{\circ}$ & & $\hat{o}$ & , & $\begin{array}{l}\sim \\
i\end{array}$ & , & 1 & 1 & ' & ' & & , & , & & ' \\
\hline & $\stackrel{0}{0}$ & $\overline{\widetilde{i}}$ & & ' & ' & ' & & ' & ' & ' & & $\stackrel{?}{-}$ & & ' & 1 & & 1 & ' & ' & 1 & $\begin{array}{l}m \\
m \\
m\end{array}$ & & ' & 1 & & ' \\
\hline & 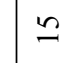 & $\stackrel{+}{\leftrightarrows}$ & & $\stackrel{\Xi}{\leftrightarrows}$ & ' & ' & & ' & ' & ' & & 1 & & $\stackrel{t}{0}$ & $\tilde{3}$ & & 1 & $\mid \begin{array}{l}0 \\
\dot{\Xi}\end{array}$ & 1 & 1 & ' & & 1 & , & & ' \\
\hline 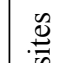 & \pm & $\begin{array}{l}0 \\
\dot{0}\end{array}$ & & 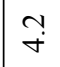 & ' & ' & & ' & $\stackrel{⿱ 亠 乂}{\sim}$ & ' & & ' & & ' & ' & & 1 & 1 & $\underset{\infty}{+}$ & 1 & ' & & , & ' & & ' \\
\hline$\stackrel{0}{\leftrightarrows}$ & $\cong$ & ले & & $\stackrel{r}{f}$ & ' & ' & & ' & $\stackrel{\circ}{-}$ & ' & & ' & & ' & ' & & $\stackrel{\infty}{=}$ & 1 & 1 & 1 & , & & , & $\begin{array}{l}\infty \\
0\end{array}$ & & ' \\
\hline ڤ్ & $\simeq$ & $\vec{n}$ & & ' & , & $\stackrel{\dot{r}}{\dot{m}}$ & & ' & $\underset{r}{\ddot{r}}$ & , & & ' & & 1 & , & & $\vec{a}$ & 1 & $\stackrel{?}{=}$ & $\begin{array}{l}\infty \\
\infty \\
\infty\end{array}$ & ' & & ' & , & & ' \\
\hline & $=$ & $\begin{array}{l}0 \\
i n \\
\end{array}$ & & ' & $\vec{i}$ & ' & & 1 & ' & ' & & ' & & 1 & 1 & & ' & 1 & 1 & 1 & $\hat{o}$ & & ' & 1 & & ' \\
\hline & $\stackrel{\circ}{\circ}$ & $\begin{array}{l}0 \\
\stackrel{\text { d }}{\circ}\end{array}$ & & $\stackrel{0}{0}$ & ' & ' & & ' & ' & ' & & $\stackrel{\varphi}{0}$ & & ' & ' & & ' & ' & ' & 1 & $\stackrel{0}{0}$ & & ' & ' & & ' \\
\hline & $a$ & $\hat{\beta}$ & & $\exists$ & ' & ' & & $\ddot{m}$ & ' & ' & & ' & & ' & ' & & , & , & 1 & ' & , & & $\tilde{i}$ & , & & $\stackrel{i}{i}$ \\
\hline & $\infty$ & ?3. & & $\underset{i}{0}$ & ' & ' & & ' & ' & ' & & ' & & ' & ' & & 1 & 1 & 1 & , & , & & , & ' & & , \\
\hline & $r$ & $\begin{array}{l}\dot{r} \\
\ddot{d}\end{array}$ & & ' & ' & ' & & ' & ' & ' & & ' & & ' & 1 & & ' & ' & 1 & 1 & 1 & & 1 & $\stackrel{\circ}{-}$ & & ' \\
\hline & 0 & $\begin{array}{l}0 \\
\dot{i} \\
\end{array}$ & & ' & ' & ' & & ' & ' & ' & & ' & & ' & 1 & & ' & ' & 1 & 1 & 1 & & 1 & ' & & ' \\
\hline & $n$ & $\stackrel{+}{+}$ & & $\vec{r}$ & $\ddot{0}$ & ' & & I & ' & ' & & ' & & ' & ' & & 1 & 1 & 1 & $\hat{\sigma}$ & 1 & & $\vec{i}$ & ' & & ' \\
\hline & $\nabla$ & 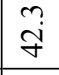 & & $\stackrel{9}{-}$ & ' & ' & & ' & ' & ' & & ' & & ' & 1 & & $\stackrel{n}{=}$ & 1 & 1 & 1 & ' & & $\begin{array}{l}\infty \\
\dot{n}\end{array}$ & ' & & ' \\
\hline & n & 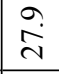 & & , & ' & ' & & & $\stackrel{m}{i}$ & ' & & ' & & ' & 1 & & ' & , & , & 1 & . & & , & , & & , \\
\hline & $N$ & $\begin{array}{c}1 \\
\infty \\
\infty\end{array}$ & & $\stackrel{0}{-}$ & ' & $\ddot{0}$ & & $\hat{i}$ & $\tilde{s}_{i}^{n}$ & ' & & ' & & $\stackrel{\infty}{-}$ & $\tilde{o}$ & & $\begin{array}{l}\infty \\
\emptyset \\
\sigma\end{array}$ & 1 & ' & 1 & , & & $\underset{0}{\infty}$ & 1 & & ' \\
\hline & - & $\stackrel{n}{ \pm}$ & & ' & ' & ' & & ' & $\ddot{n}$ & , & & ' & & ' & 1 & & $\stackrel{0}{-}$ & 1 & $\stackrel{m}{0}$ & , & , & & ' & ?ִ & & ' \\
\hline & 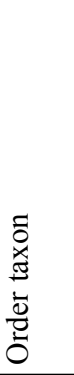 & 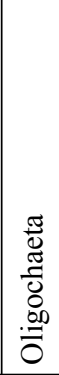 & 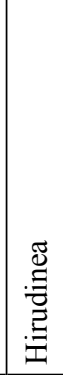 & 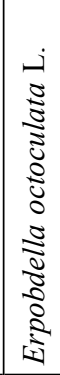 & 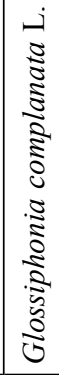 & 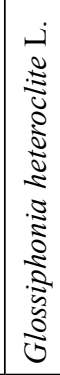 & 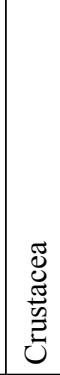 & 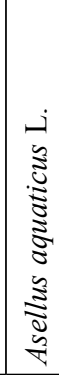 & 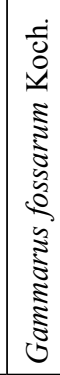 & 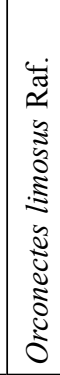 & 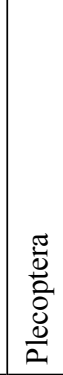 & 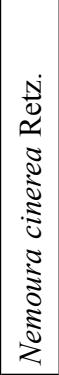 & $\begin{array}{l}\frac{\pi}{\pi} \\
\frac{\pi}{0} \\
0 \\
0\end{array}$ & 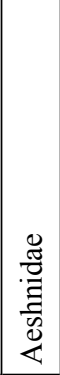 & 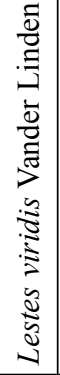 & 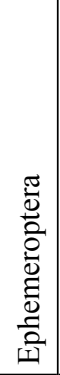 & $\begin{array}{l}\dot{0} \\
\dot{z} \\
\tilde{Z} \\
0\end{array}$ & 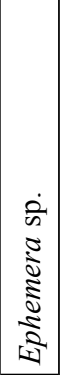 & 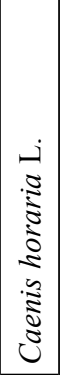 & 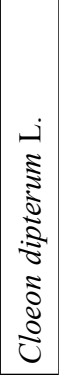 & 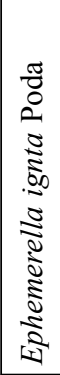 & 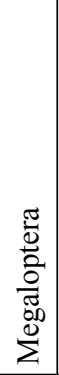 & 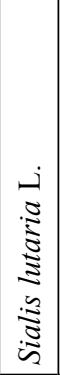 & 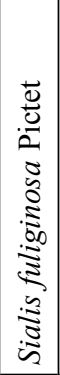 & 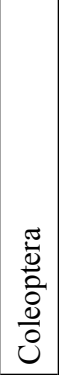 & 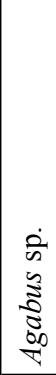 \\
\hline
\end{tabular}




\begin{tabular}{|c|c|c|c|c|c|c|c|c|c|c|c|c|c|c|c|c|c|c|c|c|c|c|c|c|c|c|c|}
\hline & 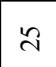 & ' & $\stackrel{\sim}{m}$ & 1 & ' & ' & & ' & ' & & ' & $\ddot{9}$ & $\stackrel{\infty}{0}_{0}$ & ' & ' & & ' & & $\begin{array}{l}n \\
6\end{array}$ & ' & 1 & 1 & \begin{tabular}{|l|}
$n$ \\
$n$ \\
$m$
\end{tabular} & & ' & ' & 6 \\
\hline & $\stackrel{\Delta}{\sim}$ & ' & & , & ' & ' & & , & , & & ' & $\stackrel{2}{2}$ & $\stackrel{\dot{m}}{ }$ & ' & $\stackrel{?}{=}$ & & ' & & ' & , & 1 & , & ' & & ' & , & $r$ \\
\hline & $\hat{\imath}$ & ' & & ' & ' & ' & & 1 & , & & ' & $\ddot{\sigma}$ & ' & , & & & ' & & ' & ' & 1 & ' & ' & & 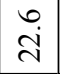 & 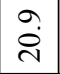 & in \\
\hline & तี & ' & & 1 & 1 & ' & & ' & ' & & , & $\begin{array}{l}\dot{t} \\
\stackrel{6}{n}\end{array}$ & ' & ' & ' & & ' & & $\begin{array}{l}0 \\
\dot{m}\end{array}$ & 1 & ' & 1 & ' & & ' & ' & in \\
\hline & $\vec{\sim}$ & ' & & 1 & ' & ' & & ' & ' & & ' & $\frac{m}{6}$ & ' & ? & ' & & ' & & ' & ' & ' & ' & ' & & ' & ' & in \\
\hline & ৯ิ & ' & $\begin{array}{l}0 \\
i\end{array}$ & , & ' & ' & & $\exists$ & ชั & & ' & $\stackrel{9}{\beth}$ & . & ' & ' & & ' & & 字 & 1 & 1 & ' & ' & & $\mid \begin{array}{l}\infty \\
\dot{\sim}\end{array}$ & , & r \\
\hline & $\stackrel{2}{ }$ & ' & & ' & ' & ' & & ' & ' & & , & $\begin{array}{l}m \\
0 \\
0\end{array}$ & ' & ' & ' & & ' & & $\stackrel{t}{0}$ & ' & $\stackrel{t}{0}$ & 1 & 1 & & 1 & 1 & in \\
\hline & $\infty$ & ' & $\stackrel{\circ}{i}$ & ' & ' & 1 & & $\hat{0}$ & $\exists$ & & ' & $\stackrel{+}{\stackrel{ \pm}{\beth}}$ & $\underset{\overbrace{}}{\mathcal{\gamma}}$ & ' & $\hat{i}$ & & , & & $\begin{array}{l}\infty \\
i\end{array}$ & $\stackrel{\text { ạ }}{a}$ & 1 & ' & ' & & , & , & $=$ \\
\hline & $=$ & ' & & , & ' & ' & & ' & ' & & ' & $\overrightarrow{\mathrm{N}}$ & ' & ' & 1 & & ' & & 1 & ' & 1 & 1 & $\stackrel{\sim}{i}$ & & $\begin{array}{l}\stackrel{\circ}{=} \\
=\end{array}$ & ' & 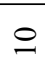 \\
\hline & 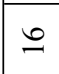 & ' & & 1 & ' & ' & & 1 & ' & & 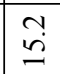 & \begin{tabular}{|c|} 
\\
i
\end{tabular} & ' & ' & ' & & ' & & $\stackrel{m}{-}$ & 1 & ' & 1 & $\stackrel{?}{=}$ & & $\begin{array}{l}0 \\
i n \\
\end{array}$ & $\because$ & $a$ \\
\hline & $\because$ & ' & & $\stackrel{\ominus}{\rightarrow}$ & ' & ' & & 1 & ' & & ' & $\hat{\sigma}$ & ' & ' & ' & & ' & & $\ddot{0}$ & 1 & ' & ' & ' & & $\stackrel{n}{i}$ & ' & $a$ \\
\hline$\stackrel{\mathscr{\omega}}{=}$ & \pm & ' & & ' & $\stackrel{\sim}{m}$ & ' & & ' & ' & & ' & $\stackrel{+}{+}$ & ' & $=$ & $\stackrel{\circ}{+}$ & & ' & & $\exists$ & 1 & ' & ' & ' & & ?̧] & ' & 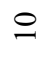 \\
\hline$\stackrel{\text { D. }}{\Xi}$ & 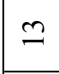 & ' & & $\stackrel{?}{+}$ & $\stackrel{+}{0}$ & ' & & ' & ' & & $\begin{array}{l}\tilde{N} \\
\tilde{N}\end{array}$ & $\begin{array}{l}\infty \\
\text { ते }\end{array}$ & $\stackrel{n}{0}$ & $\stackrel{\infty}{0}$ & ' & & $\begin{array}{l}\infty \\
0 \\
0\end{array}$ & & $\begin{array}{l}0 \\
\mathfrak{I} \\
\end{array}$ & 1 & ' & ' & 1 & & $\stackrel{m}{i}$ & $\stackrel{0}{-}$ & $\stackrel{2}{\sim}$ \\
\hline$\tilde{n}$ & $\simeq$ & ' & & ' & ' & $\underset{r}{\dot{r}}$ & & ' & , & & , & ָ̃ & ' & ' & 1 & & ' & & $\stackrel{+}{\rightarrow}$ & $\stackrel{o}{i}$ & 1 & ' & ' & & & , & 으 \\
\hline & $=$ & ' & & 1 & 1 & 1 & & ' & ' & & ' & \begin{tabular}{|l|} 
\\
$\dot{m}$
\end{tabular} & ' & ' & ' & & ' & & $\hat{o}$ & $\tilde{o}$ & 1 & 1 & $\grave{o}$ & & $\begin{array}{l}n \\
i n\end{array}$ & ' & $\infty$ \\
\hline & $\circ$ & ' & & 1 & ' & ' & & ' & ' & & ' & \begin{tabular}{|l|l|}
$\infty$ \\
$\stackrel{\infty}{2}$
\end{tabular} & ' & ' & ' & & ' & & 1 & 1 & 1 & 1 & ' & & $\tilde{o}$ & $\overrightarrow{0}$ & $r$ \\
\hline & $a$ & กี & & 1 & ' & ' & & ' & ' & & ' & $\stackrel{\sim}{\stackrel{\sim}{\sim}}$ & ' & ' & ' & & ' & & 1 & 1 & $\exists$ & $=$ & ' & & $\exists$ & ' & 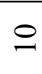 \\
\hline & $\infty$ & ' & & ' & ' & ' & & ' & ' & & ' & $\begin{array}{l}+\dot{\infty} \\
\infty\end{array}$ & , & ' & ' & & ' & & , & , & , & , & , & & $\begin{array}{l}\underset{i}{i} \\
\text {. }\end{array}$ & , & $\nabla$ \\
\hline & $r$ & ' & & 1 & ' & ' & & 1 & ' & & ' & $\begin{array}{l}0 \\
\text { तें }\end{array}$ & $\begin{array}{l}\infty \\
\ddot{\sim}\end{array}$ & , & 1 & & ' & & 1 & ' & ' & ' & ' & & $\begin{array}{l}0 \\
\ddot{\dot{\theta}} \\
\end{array}$ & ' & $n$ \\
\hline & 0 & ' & & ' & ' & ' & & ' & ' & & ' & $\stackrel{\dot{r}}{\dot{r}}$ & , & $\ddot{o}$ & ' & & ' & & ' & ' & ' & ' & ' & & $\frac{a}{i}$ & , & $\sigma$ \\
\hline & in & ' & & 1 & ' & 1 & & 1 & ' & & ' & $\begin{array}{l}0 \\
\dot{m} \\
m\end{array}$ & ' & $\underset{+}{+}$ & ' & & , & & הֶ. & ì & 1 & , & . & & $\begin{array}{l}+ \\
\infty\end{array}$ & $\begin{array}{l}\infty \\
\ddot{2} \\
\end{array}$ & $\simeq$ \\
\hline & $\nabla$ & ' & & ' & ' & ' & & , & ' & & $\begin{array}{l}\infty \\
\infty\end{array}$ & $\begin{array}{l}0 \\
0 \\
0\end{array}$ & ' & ' & $\stackrel{\infty}{i}$ & & , & & ' & ' & 1 & ' & , & & $\underset{\sim}{\stackrel{\sim}{*}}$ & $\ddot{a}$ & 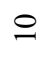 \\
\hline & $m$ & ' & & ' & 1 & 1 & & 1 & ' & & ' & $\stackrel{\varphi}{=}$ & ' & ' & ' & & ' & & \begin{tabular}{|l|}
$\stackrel{+}{ \pm}$ \\
\end{tabular} & ' & ' & ' & ' & & ' & $\begin{array}{l}n \\
\dot{m}\end{array}$ & 0 \\
\hline & N & , & & 1 & ' & ' & & ' & ' & & ' & $\begin{array}{l}\infty \\
\dot{0}\end{array}$ & , & ' & ' & & ' & & 1 & $\stackrel{n}{r}$ & 1 & , & , & & $\underset{\sigma}{\sigma}$ & $\begin{array}{l}0 \\
\mathrm{I}\end{array}$ & $\cong$ \\
\hline & - & ' & & 1 & 1 & I & & 1 & ' & & ' & \begin{tabular}{|l|}
$\infty$ \\
$\dot{\rho}$
\end{tabular} & ' & ' & @े & & , & & 1 & ' & 1 & ' & , & & ' & \begin{tabular}{|c|}
$\dot{0}$ \\
$\ddot{2}$
\end{tabular} & $\infty$ \\
\hline & 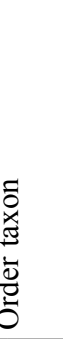 & 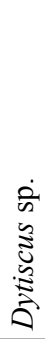 & 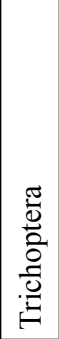 & 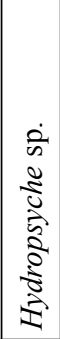 & 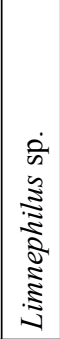 & 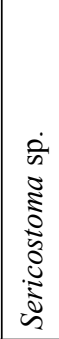 & 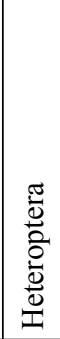 & 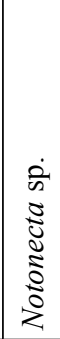 & 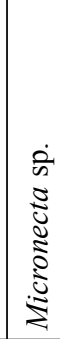 & $\mid \begin{array}{l}\frac{\pi}{0} \\
\stackrel{0}{0} \\
\ddot{n}\end{array}$ & 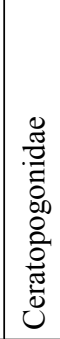 & 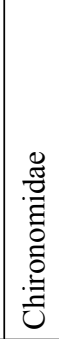 & 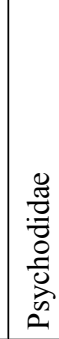 & 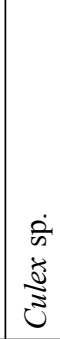 & 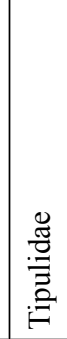 & 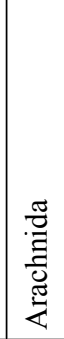 & 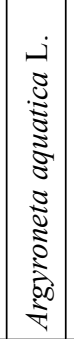 & 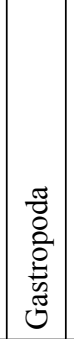 & 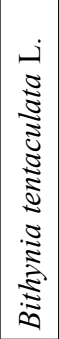 & 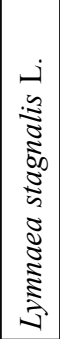 & 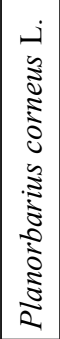 & 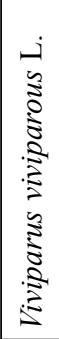 & 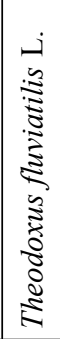 & 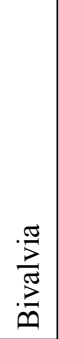 & 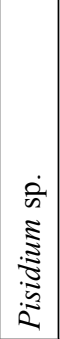 & 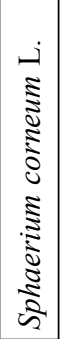 & 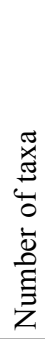 \\
\hline
\end{tabular}




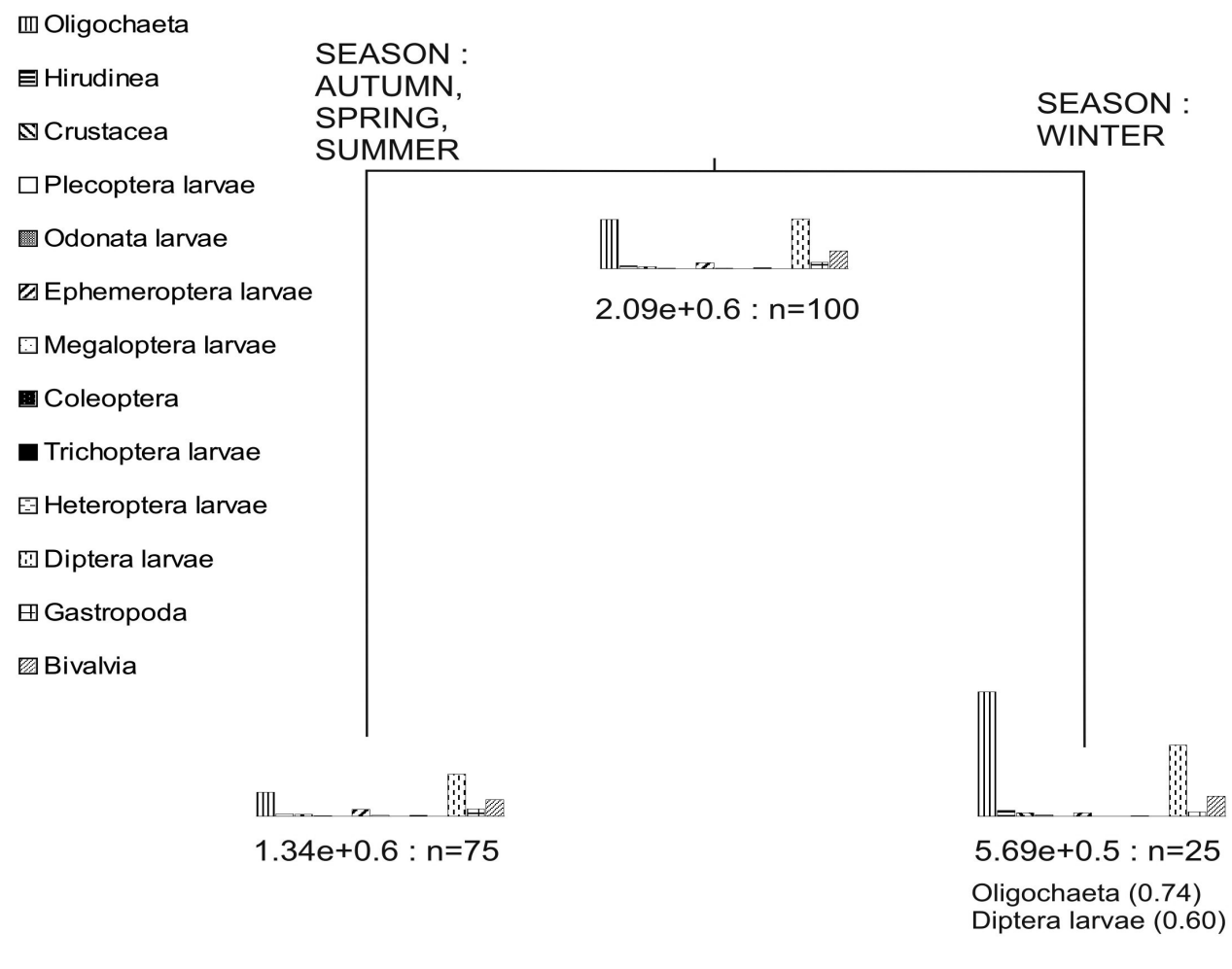

Error : 0.915 CV Error : 1.24 SE : 0.302

Figure 3. Multivariate regression tree for macrozoobenthos density

\section{Discussion}

During the studied period, filamentous algae communities, assemblages of Elodeetum canadensis and communities of Glycerietum maximae were the dominant components of aquatic flora in the Stupia River within the limits of Stupsk. Considerable contribution of filamentous algae (sampling sites 9-13 and 19-21) can be attributed to the increase in trophy caused by the point-source inflow of nutrients, mainly nitrogen and phosphorus compounds. Phytocoenoses of Elodeetum canadensis formed in the river almost mono-species aggregations- individual or in complexes with other communities (e.g. Ranunculetum fluitantis). Their appearance, usually connected with high biomass production and elimination of other communities, is indicative for eutrophic waters (Matuszkiewicz 2001). Further contamination of riverine waters in Słupsk may result in more intense expansion of Elodea canadensis, posing a real threat to a rare assemblage, typical for clean rivers with sandy bottom, namely Ranunculetum fluitantis.
As for the assemblage of Glycerietum maximae, it prefers eutrophic waters with muddy substrate and probably is highly tolerant of water pollution (Matuszkiewicz 2001). The presence of abundant Ranunculetum fluitantis phytocoenoses at the last studied kilometre of the Stupia River (sampling sites 22, 24 and 25) indicates the improvement in water purity.

MRT analysis revealed a significant distinctness of aquatic flora at the first 5 sampling sites. Sparganium emersum and Callitriche hamulata communities were observed only before the city. Probably they prefer similar habitat conditions as for flow velocity and water chemistry. According to Matuszkiewicz (2001) Sparganium emersum is characteristic to complex Ranunculion fluitantis, while Callitriche hamulata is typical for complex Ranunculo-Callitrichetum hamulatae Oberd. 1957 em. Müll. 1977 - a community of clear, cool water with high flow velocity. Both phytocoenoses may be important bioindicators of riverine water contamination and therefore should be further studied from phytosociological and ecological point of view. 


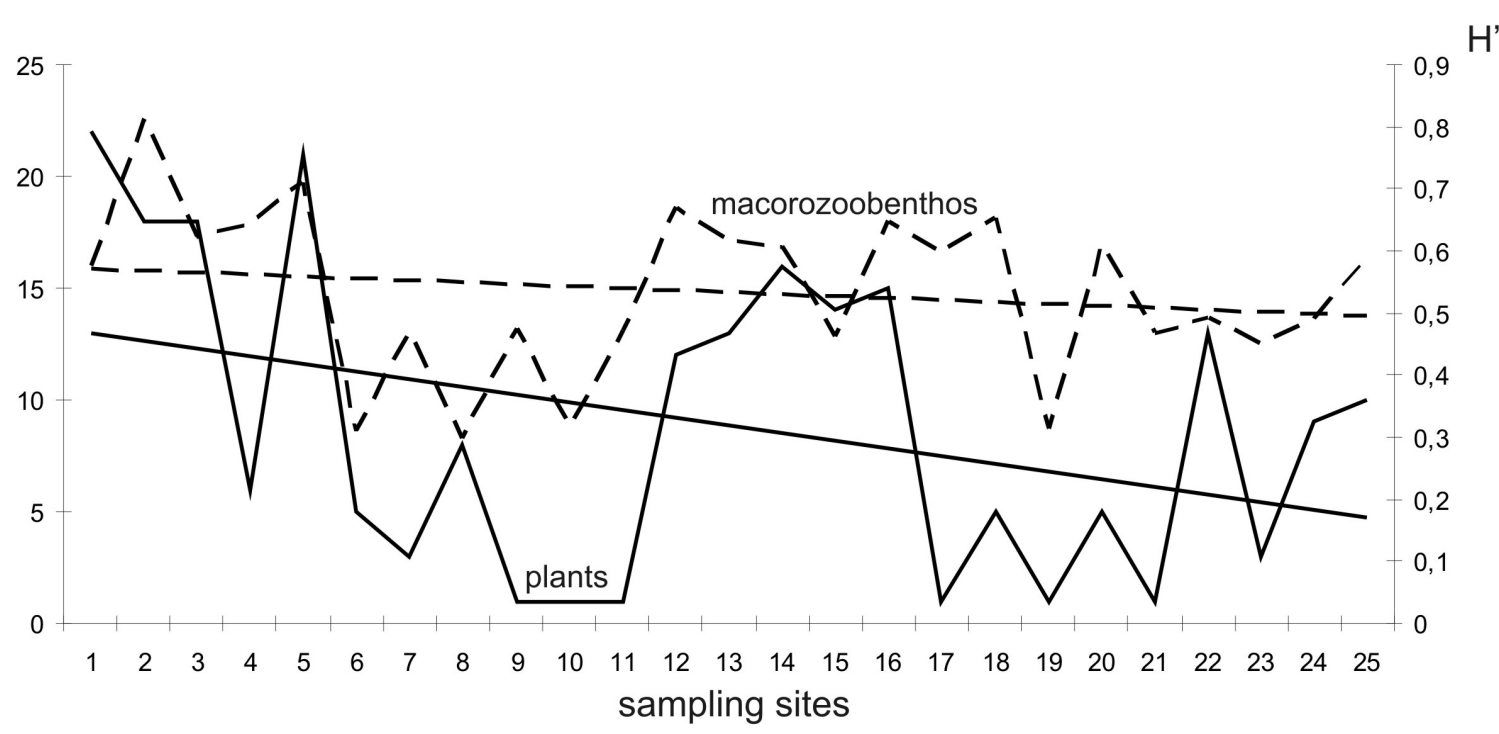

Figure 4. Biodiversity of plants and benthofauna ( $\left.\mathrm{H}^{\prime}\right)$ at the consecutive sampling sites

Analysis of bioindicative properties of the consecutive plant communities revealed that water flowing into the urban area is mesotrophic or slightly eutrophic (Callitriche hamulata community as an indicator). In the middle of the conurbation, urban agglomeration water becomes highly contaminated and eutrophic (filamentous algae, Glycerietum maximae), while self-purification processes diminish the contamination outside the city (Ranunculetum fluitantis)

MRT analysis of macrozoobenthos revealed significant differences in benthofauna structure and density between seasons. The commonly known influence of seasonality on life cycles of aquatic organisms may cause considerable fluctuations in the abundance of hydrobionts spending in water only their larval stage (Moog et al. 1997). Seasonality is closely related to water temperature, which also influences the structure of benthofauna (Turoboyski 1979). The performed mathematical analyses revealed the influence of both season and temperature but the latter factor is of lower importance than the former one. This can be explained by the dominant role of Oligochaeta and Diptera larvae, the occurrence of which is generally little conditioned on water temperature (Kajak 1998; Kasprzak 1986). Moreover, the riverine water flowing through the urban area can be anthropogenically warmed or cooled by damming up, municipal or industrial sewage inflow (Turoboyski 1979).

Negative influence of the urban area on hydrophytes and macrozoobenthos was confirmed by the decrease in biodiversity, which was particularly distinct in case of riverine vegetation, sensitive to contamination (Fig. 4).
Comparison of biodiversity graphs for plants and benthic fauna showed similarities in their reaction to the increase of anthropogenic pressure in the urban area, which may indicate point-source characteristics of contamination in the Słupsk area.

\section{Conclusions}

This study indicates that many parameters influence vegetation and macrozoobenthos inhabiting the Slupia River in the urbanized area. The leading factors were the type of microhabitat and anthropogenic pressure. The performed analysis constitutes the first step in the recognition of the Shupia ecological state and threats resulting from polluting the river by the city. It also should be a starting point for next studies conducted within introduction of the European Union directives in the field of aquatic policy in Poland. The proposed research method can be applied in monitoring of Polish rivers in accordance with the EU Water Framework Directive.

\section{Acknowledgements}

The scientific study was financed by $2006-2009$ and 2007-2010 educational funds as research projects $2 \mathrm{PO} 4 \mathrm{G}$ 03530 and NN 305324733. 


\section{References}

Allan J. D., 1997, Ekologia wód płynących [Ecology of running waters], PWN, Warszawa.

Barbour M. T., Gerritsen J., Griffith G. E., Frydenborg R., McCarron E., White J. S. \& Bastian M. L., 1996, A framework for biological criteria for Florida streams using benthic macroinvertebrates, Journal of the North American Benthological Society 15 (2): 185-211.

Barbour M. T., Gerritsen J., Snyder B. D. \& Stribling J. B., 1997, Revision to rapid bioassessment protocols for use in streams and rivers. Periphyton, benthic macroinvertebrates and fish.

http://www.epa./gov/owowwtr1/monitoring/AWPD/RBP/ html.

Böhmer J., Rawer-Jost C., Kappus B., Blank J., Hock C. \& Siber R., 1999, Integrierte ökologische Fließgewässerbewertung - Erarbeitung von Grundlagen zur leitbildorientierten biologischen Fließgewässerbewertung im Mittelgebirge. Handbuch Angewandte Limnologie. ecomed, Supplement, Landsberg: $52 \mathrm{pp}+68$.

Breiman L., Friedman J. H., Olshen R. A. \& Stone C. G., 1984, Classification and regression trees. Wadsworth International Group, Belmont, California, USA.

De'ath G., 2002, Multivariate regression trees: A new technique for modelling species-environment relationships, Ecology 83: 1105-1117.

De'ath G. \& Fabricus K. E., 2000, Classification and regression trees: A powerful and simple technique for ecological data analysis, Ecology 81: 3178-3192.

Dufrene M. \& Legendre P., 1997, Species assemblages and indicator species: The need for a flexible asymmetrical approach, Ecological Monographs 67: 345-366.

Ellenberg H., Weber H. R., Düll R., Wirth V., Werner W. \& Paulissen D., 1992, Zeigerwerte von Pflanzen im Mitteleuropa, 2. Aufl., Verlag Erich Goltze KG, Göttingen: 258.

European Union 2000, Directive 2000//EC of the European Parliament and of the Council of Europe establishing a framework for Community action in the field of water policy, PE-CONS 3639/00, Brussels, 30 June 2000.
ISO 4365, Liquid flow in open channels - Sediment in streams and canals - Determination of concentration, particle size distribution and relative density.

ISO 9195, Liquid flow in open channels - Sampling and analysis of gravel - bed material.

Kajak Z., 1998, Hydrobiologia - limnologia [Hydrobiology-limnology], Wydawnictwo Naukowe PWN, Warszawa.

Kasprzak K., 1986, Aquatic and terrestial Oligochaeta II. Enchytraeidae, Museum and Institute of Zoology PAN, Warszawa.

Matuszkiewicz W., 2001, Przewodnik do oznaczania zbiorowisk roślinnych Polski [Guide for identification of plant communities in Poland], Wydawnictwo Naukowe PWN, Warszawa.

McAleece N., Lambshead J., Patterson G., Gage J., 1997, BioDiversity. Profesional Beta, The Natural History Museum, London \& The Scottish Association of Marine Science, Oban, Scotland.

Medwecka-Kornaś A., Kornaś J., Pawłowski B. \& Zarzycki K., 1972, Przegląd zbiorowisk lądowych i słodkowodnych [Review of terrestial and freshwater plant communities], [in:] W. Szafer \& K. Zarzycki (eds.), Szata roślinna Polski, vol. 1 [Vegetation of Poland, vol. 1], PWN, Warszawa: 237-501.

Moog O., Bauernfeind E. \& Weichselbaumer P., 1997, The use of Ephemeroptera as saprobic indicators in Austria, [in:] P. Landolt \& M. Sartori (eds.), Ephemeroptera and Plecoptera: Biology - Ecology - Systematics, MTL, Fribourg: 254-260.

Obolewski K., Huzar J. \& Grigielis A., 2004, Annelida rzeki Słupia [Annelida of the Stupia River], Badania Fizjograficzne nad Polską zachodnią [Physiographic Studies in Western Poland], C, 50: 7-19.

Piechura J., Walczowski W. \& Beszczyńska-Möller A., 1997, On the structure and dynamics of the water in the Slupsk Furrow, Oceanologica 39: 35-54.

R Development Core Team, 2004, R: A language and environment for statistical computing, R Foundation for Statistical computing, http://www.Rproject.org.

Turoboyski L., 1979, Hydrobiologia techniczna [Technical hydrobiology], PWN, Warszawa. 